\title{
EUPHYTICA
}

\section{VOLUME 1 (1952) REPRINTED}

Since many years is Volume 1 (1952) out of print, but arrangements are being made to have it reprinted before the end of this year. The contents of this volumes arc: BANGA, O.: Some observations on the influence of the length of day on the leaf growth of red garden beets. BANGA, O.: Some factors in the growth rate of red garden beets. BREMER-Reinders, D. E. and BREMER, G.: Methods used for producing polyploid agricultural plants. CoolhaAs, C.: Large scale use of $F_{1}$ hybrids in 'Vorstenlanden' tobacco. Dorst, J. C.: A questionable novum. Dorst, J. C.: Two remarkable budsports in the potato variety Rode Star. HAAN, H. DE: Flax breeding and flax varieties in the Netherlands. Houtzagers, G.: Forest genetics and poplar breeding in the Netherlands. I. The difference between breeding work in forestry and agriculture or horticulture. HoutZaGERs, G.: Forest genetics and poplar breeding in the Netherlands II. Poplar breeding in the Netherlands. Howard, H. W. and Swaminathan, M. S.: Species differentiation in the section Tuberarium of Solanum with particular reference to the use of interspecific hybridisation in breeding. Keuls, M.: The use of the 'studentized range' in connection with an analysis of variance. LAMBERTS, H.: Resistance to mildew in yellow lupins. MASTENBROEK, C.: Investigations into the inheritance of the immunity from Phytophthora infestans DE B. of Solanum demissum LINDL. SCHAEPMan, H.: Application of the polycross test to grass breeding. Thun, G. A.: Potato varieties and powdery mildew attacks. Toxopeus, H. J.: Studies in the breeding of Derris elliptica and Derris malaccensis. I. Variation and the origin of the cultivated material. Toxopeus, H. J.: Studies in the breeding of Derris elliptica and Derris malaccensis. II. Crossbreeding, cytological observations, genetic system. Toxopeus, H. J.: A thornless variety of Mimosa invisa. VAART, F. M. VAN DE: The identification of pea varieties in the seedling stage. WeLlENSIEK, S. J.: the theoretical basis of the polycross test. WeLlensieK, S. J. and others: Vegetative seed formation? WiT, F.: The pollination of perennial ryegrass (Lolium perenne L.) in clonal plantations and polycross fields.

Many of these articles concern matters on which interest is still focussed, or which have not been rendered out of date by more recent investigations.

The price is fixed at $\$ 12.50$. Orders can be sent to Dr. A. C. Zeven, Managing Editor Euphytica, Lawickse Allee 166, Wageningen, The Netherlands. 